\title{
CITIES OF OVER A MILLION PEOPLE ON THE MORTALITY MAP OF RUSSIA
}

\section{ALEKSEI SHCHUR}

\begin{abstract}
The problem of excess mortality in Russia has not lost its relevance. The situation is complicated by the high level of spatial inequality in health, which is usually measured at the regional level in our country. This work is one of the first attempts to look at the dynamics and extent of spatial inequality in health in Russia at the sub-regional level, by contrasting the "center/core" (in our case, represented by the largest Russian cities) with the "periphery" (the rest of the country). Cities with a population of over a million people were chosen based on the spatial hierarchy that exists in Russia, according to which the highest level of social and economic development is concentrated in the largest cities. As a rule, a higher level of development of human capital corresponds to lower mortality. Using data provided by Rosstat, we calculated life expectancy at birth for Russian cities with a population of over a million people in 1989-2016. The results fully coincided with our expectations: the polarization in the health levels between the largest Russian cities and the rest of the country has significantly increased in the last twenty-five years, which is a reflection of those centripetal processes that have been taking place in our country during this period. Russian cities with a population of over a million people are attractive destinations for both internal and external migrants, and thus acquire, among other things, a much more educated population. Since people with higher education take better care of their health, having a more educated population is undoubtedly an essential advantage of bigger cities over the periphery when it comes to the overall health level. Without solving the structural problems that restrain social and economic development outside the largest agglomerations, convergence in mortality rates between cities with a population of over a million people and the surrounding territories is hardly possible.
\end{abstract}

Key words: life expectancy, spatial inequality in mortality, cities with a population of over a million people, educational level, core and periphery.

Inequality in health, like any other socio-economic, i.e. modifiable inequality, poses a serious challenge to the state and society [Shkaratan 2009: 556]. Studies of inequality consider two main types of differences: interindividual and intergroup [Andreev et al. 2001]. These include inequality between socio-demographic groups (depending on gender, race, nationality, level of education, economic status, marital status), and spatial (geographical) inequality between countries, types of populated areas (for example, urban and rural), regions and other units of administrative-territorial division.

The study of inequality in mortality is especially relevant for Russia, which is distinguished by significant gender differences in life expectancy (LE), significant regional differentiation, and one of the most significant differences in life expectancy between educational groups in the world (for countries with reliable mortality statistics) [Shkolnikov et al. 2006; Inequality and mortality ... 2000]. At the same time, Russia is far behind not only most developed countries, but also many developing countries in life expectancy at birth [WHO Mortality Database 2017]. The level of economic well-being of Russia should correspond to a much longer life expectancy [Andreev, Shkolnikov 2018].

\footnotetext{
Aleksei ShChur (aschur@hse.ru), National Research University Higher School of Economics, Russia.

THE RESEARCH WAS FUNDED UNDER THE STATE SUPPORT PROGRAMS OF THE RUSSIAN FEDERATION “THE ACADEMIC EXCELLENCE PROJECT 5-100”.
}

THE ORIGINAL ARTICLE IN RUSSIAN WAS PUBLISHED IN DEMOGRAPHIC REVIEW IN 2018, 5(4), 66-91. DOI: 10.17323/DEMREVIEW.V5I4.8663 
In this regard, studying the level of inequality in health and the factors explaining it should help shed light on the reasons for Russia's life expectancy lag behind other countries and highlight the "advanced" groups that can point to mechanisms for reducing mortality for the "rest of the population".

Russia's lag behind world leaders in life expectancy began to increase in the late 1960s and testified to the structural contradictions that had accumulated within the Soviet system [Eberstadt 1981; Vishnevsky, Shkolnikov 1997]. The USSR, like the entire Eastern Bloc, was not ready to confront new threats caused by the changed epidemiological situation - the increasing role of noninfectious causes of death. Moreover, unlike many other countries of Eastern Europe, in the 1990s the "young" Russia failed to enter a new stage of the epidemiological transition; in addition, there occurred a serious deterioration in the state of health in the country, forcing some researchers to speak even of a "reverse epidemiological transition" [Semenova 2005: 235].

The current stage of mortality reduction in Russia, which began in the mid-2000s, is interpreted by experts in different ways. Some demographers believe that the increase in life expectancy in the current period is of a restorative, "compensatory" nature and that so far there is no reason to talk about the beginning of a second epidemiological transition in Russia [Vishnevsky 2014]. Other scientists, on the contrary, note new trends in mortality in the country, which can be considered as signs of a cardiovascular revolution [Grigoriev et al. 2014]. In our opinion, the study of mortality trends in the territories that are in the vanguard of its decline in Russia can help answer the question of whether or not the changes in the mortality regime are precursors of the start of the second epidemiological transition.

Significant spatial polarization in the mortality rate, especially during periods of a sharp rise or, conversely, a rapid decline, has been observed in many Eastern European countries which, like Russia, experienced a "mortality crisis" in the second half of the 20th century. Thus, in Lithuania, the greatest life expectancy in 1988-96 was in the largest cities, and the gap in the mortality rate between urban and rural areas increased during the period of social and economic transformation [Kalediene, Petrauskiene 2000; Kalediene, Petrauskiene 2004]. A similar picture was observed in the two other Baltic countries [Krumins et al 2009]. In Belarus, perhaps the state most similar to Russia in socio-cultural terms, since the second half of the 1990s there has been a pronounced trend towards a divergence in the mortality rate between the capital and the rest of the country. In this same period a similar process took place in our country. An analysis of the intraregional mortality rate conducted for Belarus by Pavel Grigoriev and co-authors showed that in all regional centers, as well as in other major cities which are separate administrative units of the second level (analogous to Russian regions and urban districts), the mortality rate is significantly lower than in the surrounding areas [Grigoriev, Doblhammer-Reiter, Shkolnikov 2013]. There is every reason to believe that a similar picture can be seen in Russia.

Due to Russia's large size and climatic, socio-economic, ethnic and other diversity, both Russian and foreign scientists pay special attention to studying the trends and scales of differences in the level of mortality in a regional context [Vasin, Costello 1997; Shkolnikov, Vasin 1994; Vallin et al. 2005; Timonin et al. 2017]. Even in Soviet times it was shown that there existed a southwest/northeast mortality gradient in Russia (RSFSR) [Andreev 1979; Shkolnikov 1987] which remains relevant to this day [Timonin et al. 2017]. In addition, there is a special "privileged" 
place on the "mortality map" of Russia of St. Petersburg and especially of Moscow. Mortality levels and trends in these cities are often contrasted with those of the rest of Russia [Andreev, Kvasha, Kharkova 2006; Kvasha, Kharkov 2009]. At the same time, Moscow and St. Petersburg, despite all the recent successes in reducing mortality, lag significantly behind Western megacities in terms of life expectancy [Andreev, Kvasha, Kharkov 2016].

The socioeconomic situation and educational structure of the population do indeed distinguish the former and current capitals of Russia from the rest of its territory, while at the same time the country's other major population centers, above all cities with a population of over one million people ('million-plus cities'), are also very often considered as reference points of the country's modernization, its educational and economic centers, places of attraction of people [Zubarevich 2010]. In this regard, it is interesting to conduct a comparative analysis of the main mortality trends in the two capitals, along with other "non-capital" cities with a population of over one million, with their surrounding territories (regions whose administrative centers they are), as well as with the rest of the country. This will help to answer the question of whether the largest cities in Russia are in the forefront of its decreasing mortality, as well as to assess the dynamics and size of the gaps in life expectancy between them and their regions.

\section{DATA AND METHODS}

The object of study in this work are the cities of Russia in which the resident population exceeds one million people. The work is based on data of state statistics of Russia for 1989-2016 on the distribution of deaths by sex and five-year age groups $(0 ; 1-4 ; \ldots 85+)$ for selected Russian cities whose population as of January 1, 2017 exceeded one million people (data on the resident population of cities within their administrative boundaries taken according to Rosstat). To calculate life expectancy at birth in million-plus cities and in the rest of the regions of which they are the administrative centers, brief mortality tables were constructed. It should be said that, in the opinion of many demographers, the quality of the censuses of 2002 and 2010 in Moscow causes great concern [Andreev 2012; Mkrtchyan 2012]. Particularly acute is the problem of overstating the number of Muscovites in the oldest age groups, which leads to an upward distortion of Moscow's indicators of life expectancy at birth [Papanova et al. 2017]. Following the work of Papanova and co-authors, in order to obtain more realistic estimates of life expectancy at birth we adjusted the mortality tables calculated for Moscow using the methodology used in the Human Life Table Database. The essence of the correction lies in modifying $a_{85+}+$ by selecting such a value $\mathrm{a}_{85}\left(=1 / \mathrm{m}_{85+}\right)$ which empirically (based on a comparison of the entire array of mortality tables constructed for countries with high-quality statistics) would correspond to the observed value of $\mathrm{e}_{0}$ [Shkolnikov V.M. et al. 2017: Appendix 1].

As of January 1, 2017, there were 15 cities in Russia with a permanent population of over one million people ${ }^{1}$. Taking into account the significant differences in the population size between Moscow and St. Petersburg, on the one hand, and other largest populated areas of Russia, on the

\footnotetext{
${ }^{1}$ The number and composition of million-plus cities in Russia in 1989-2016 underwent certain changes (Appendix 1). For a time comparison we will look at all fifteen cities for each year, even if not all of them had a population exceeding one million during every one.
} 
other (the total population of the two capital cities in recent years exceeds the total population of all other million-plus Russian cities), it seems reasonable to study Moscow and St. Petersburg separately and the remaining million-plus cities together. To do this, we introduced a new category - the aggregate city, the set of non-capital million-plus cities (i.e. all Russian million-plus cities except Moscow and St. Petersburg), for which all indicators are calculated by adding the numbers of the deaths and the population size of all cities in the set.

All Russian million-plus cities, with the exception of Moscow and St. Petersburg, are also the administrative centers of various regions (oblasts, republics and krays) and concentrate a significant part of the population and economic potential of the respective regions. To determine the mortality rate in these regions beyond the regional centers, we calculated the values of life expectancy at birth for these regions without including the population living in the centers of the regions (million-plus cities) and the deaths recorded in them. For convenience of comparison, the category of aggregate region was created analogous to the aggregate city. In addition, we calculated the life expectancy for the rest of Russia, which would not include the population of million-plus cities, as well as the population of the North Caucasian Federal District (NCFD) 2 , i.e., in essence, for Russia without its biggest cities.

The main limitation of this work arises from a certain imperfection of methods for collecting and processing official data by Russian statistics, which can lead to the problem of numerator/denominator bias when calculating mortality rates and, therefore, when constructing mortality tables. Thus, a person's death can be registered not only at the place of his legal residence (where he is listed as the denominator - the permanent population), but also at the place of his death. This is especially true for large cities, which are centers of attraction for migrants who are not taken into account by statistics, as well as foother subjecsr patients who go for treatment to the large administrative center of their region or to Moscow and die there [Demographic Situation ... 2006: 264].

The "denominator problem" is even more acute. First, the inter-census population estimates for all million-plus cities except Moscow and St. Petersburg are not recalculated from the results of the last census, which is clearly seen in the graph of the size of the permanent population of the aggregate city for the years 1989-2017. (Appendix 2). Here you can also observe the impact of changes in the practice of statistical accounting at the end of the Soviet period: the populations of Samara, Perm, Nizhny Novgorod, Krasnoyarsk, Chelyabinsk, and Yekaterinburg as of January 1, 1989 included the population of CATE (Closed Administrative-Territorial Entities, a total of 200 thousand people), but starting from January 1, 1990 Rosstat excluded the CATE population from estimates of the permanent population of these cities. Another aspect is the quality of the 2002 and 2010 censuses conducted in Russia, especially in Moscow and the republics of the North Caucasus [Andreev 2012] (in many respects this is why the latter were completely excluded from our research). These two censuses are flawed by double counting of some groups ofwit the population (students, men of military age) and undercounting of others (foreigners, migrant workers), and by an abuse of administrative databases that do not always reflect the current situation (above all, they underestimate emigration), which leads to the problem of "immortal seniors", which can be clearly

\footnotetext{
${ }^{2}$ The NCFD is not included due to a number of doubts about the quality of data in the district. 
observed in Moscow and St. Petersburg (Appendix 3). At the same time, the adjustments made in response to these limitations to the research methodology somewhat reduced the effect of these problems on the results obtained.

\section{RESULTS}

In Figure 1, beginning in the second half of the 1990s, a significant divergence of life expectancy at birth between Moscow and St. Petersburg (and to a lesser extent, other million-plus cities), on the one hand, and the rest of Russia on the other can be observed. The turning point was $1994^{3}$, after which mortality in the largest cities of the country (and, especially, in the two capitals) began to decline at a faster pace. The increase in mortality in the early 2000s was also more intense in the rest of Russia ${ }^{4}$, which only increased the gap in life expectancy between the "periphery" and the "center", represented in our study by the largest cities with a population of over one million people. The gap between the maximum and minimum life expectancy during this period (19942005) increased from 1.36 years for men and 1.05 years for women to 9.18 (8.98 according to adjusted data) and 4.67 (4.63) years, respectively (Figure 1). Particularly significant is the difference between Moscow and both the rest of the country and the other million-plus cities, including St. Petersburg, where mortality remains lower than in all other cities under consideration. The rise in mortality that took place in Russia in the first half of the 2000s affected the largest cities of the country to a lesser extent (as noted above) and almost did not affect Moscow, which strongly distinguishes it from the other regions of the Russian Federation ${ }^{5}$.

The reduction in mortality which began in Russia in 2004 differs from the previous short periods of its reduction by its record (for the period from 1965) duration [Shkolnikov et al. 2013]. However, the increase in life expectancy observed in this period in all regions of the country was not accompanied by any significant reduction in inequality in mortality between the "capitals" (Moscow and St. Petersburg) and the rest of Russia. At the same time, the highest rates of increase in life expectancy in 2004-2016 were recorded in St. Petersburg, which allowed it to significantly break away from the aggregate city and reduce its lag behind Moscow. Moreover, the weak (relative to both capitals and the rest of the country) dynamics of life expectancy of the male population in the aggregate city in the 2010s draws attention. In most million-plus cities during this period, mortality from some of the causes of death due to alcohol abuse (poisoning, cirrhosis) stops or even increases, but similar processes occur in Russia as a whole. What really distinguishes the situation in the aggregate city from the rest of the country during this period is the much higher mortality rate from the disease caused by HIV [Shchur 2018: 109].

\footnotetext{
${ }^{3}$ The year with the lowest life expectancy at birth in Russia for at least the last 50 years.

${ }^{4}$ While the increase in mortality in the early 1990s was more pronounced in large cities [Shkolnikov et al 1998: 1995-2011].

${ }^{5}$ In addition to Moscow, the minimum increase in mortality was observed in the North Caucasian republics, as well as in the "oil and gas" districts (Khanty-Mansi Autonomous Okrug, Yamal-Nenets Autonomous Okrug).
} 


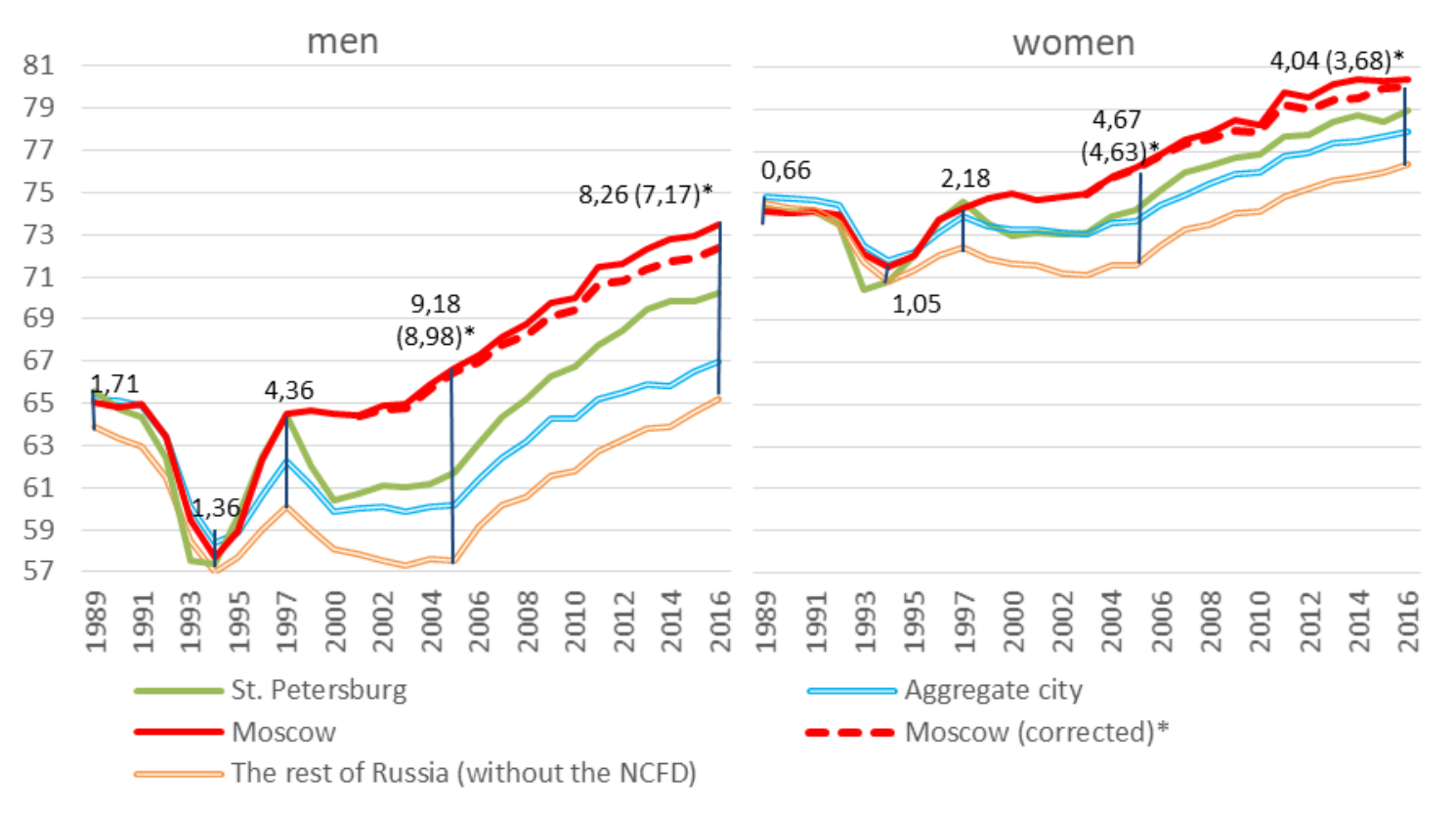

Figure 1. Life expectancy at birth in Moscow, St. Petersburg, the aggregate city and the rest of Russia (without the North Caucasus Federal District), 1989-2016, years

Note: The vertical lines in the graph show the range between the maximum and minimum values in the selected years.

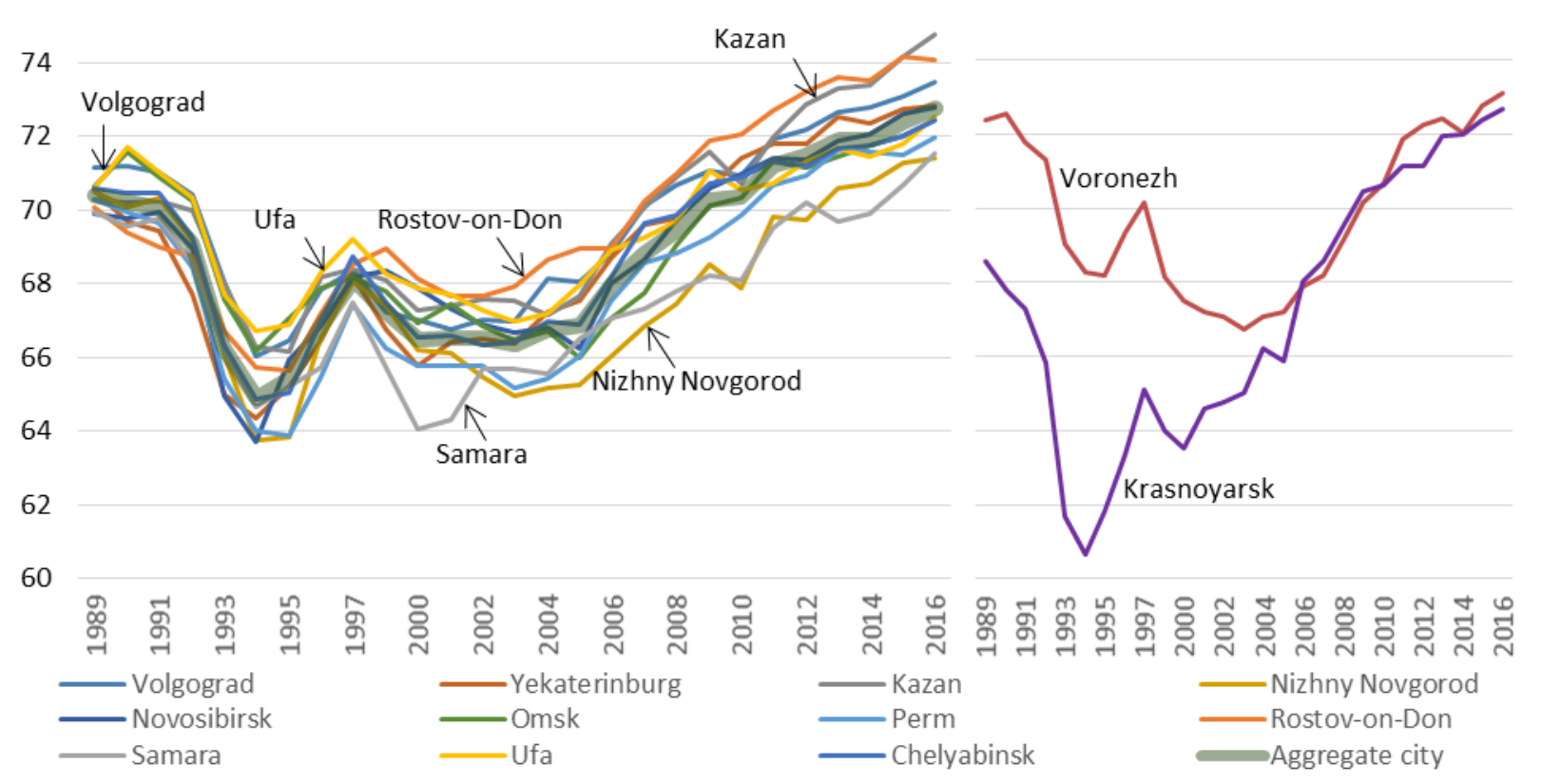

Figure 2. Life expectancy at birth in million-plus cities (except Moscow and St. Petersburg) and the aggregate city, 1989-2016, years $^{6}$

Figure 2 shows the dynamics of life expectancy at birth in million-plus cities with the exception of Moscow and St. Petersburg. From this it can be seen that in the period under study million-plus cities showed the same fluctuations characteristic of Russia as a whole. Nevertheless, the range of these fluctuations was different for different cities, which determined the increase in

\footnotetext{
${ }^{6}$ See Appendix 4.
} 
the gap between the maximum and minimum life expectancy from 1.26 years in 1989 to 3.37 years in 2016 (the standard deviation for 11 million-plus cities ${ }^{7}$ for the same period increased from 0.37 years to 1.02 years - Appendix 5). In the 1990s, the highest life expectancy was noted alternately in Volgograd, Ufa and Omsk, and the lowest in Novosibirsk, Yekaterinburg and Perm. In the 2000s the picture changed: there was a group of "laggards" (Samara and Nizhny Novgorod), significantly lagging behind other million-plus cities, and a duo of "leaders" (Kazan and Rostov-on-Don) where mortality was significantly lower than the national one.

Traditional factors affecting the mortality rate, such as the level of education of the population or the level of socio-economic development of the territory, do not, as will be shown below in the Discussion section, fully explain the differences in life expectancy between Russian million-plus cities. Nor was it possible to find any connection between the size of the city (its population) or geographical location (belonging to one or another Russian macro-region) and the magnitude of life expectancy. If we turn to the group of cities in which a reduced mortality rate (relative to the aggregate city) is currently recorded, they are united either by more favorable climatic conditions (Volgograd, Voronezh, Rostov-on-Don), or by being among the leaders in the development of tertiary sectors of the economy with a corresponding employment structure 8 (Ekaterinburg and Novosibirsk, and partly Kazan and Rostov-on-Don).

I would like to look in particular at the comparison of Krasnoyarsk and Voronezh. Until the beginning of the 2010s neither of these was a million-plus city, and in the 1990s in terms of life expectancy they were poles apart, significantly better (Voronezh) and worse (Krasnoyarsk) than all other cities studied. In 1994, life expectancy in Krasnoyarsk lagged behind that in Voronezh by almost 8 years. But by 2006 Krasnoyarsk had overtaken Voronezh, and since then both cities have had a generally similar mortality rate. A possible explanation for such a strong gap in life expectancy in the early 1990s and its subsequent reduction to a minimum by the mid-2000s is the different reactions of the two populations to "shock therapy", as well as the different depths and speeds of market reforms in the "patriarchal" Black Earth Region , a former part of the "Red Belt", and in Eastern Siberia (a newly developed region with a large number of newcomers who turned out to be particularly vulnerable to a radical restructuring of the socio-economic system) [Walberg et al 1998].

Figure 3 shows the dynamics of life expectancy at birth in million-plus cities and in other populated areas of their regions in 1989 and 2016. During the period under consideration, the differences in life expectancy between the "centers" and the "periphery" increased significantly in all the regions studied. If in 1989 the life expectancy in the aggregate city was 0.8 years higher than in the aggregate region, in 2016 the gap increased to almost 2.5 years. In all the regions of the federation shown in Figure 3, including the two "capital regions" (Appendix 6), life expectancy in the administrative centers in 1989-2016 grew at a much faster pace than in other populated areas. In a number of regions, such as the Sverdlovsk and Chelyabinsk regions, life expectancy outside the regional centers in 2016 still had not reached the 1989 level.

\footnotetext{
${ }^{7}$ Without Voronezh and Krasnoyarsk

${ }^{8}$ A higher share of people engaged in mental work ("white collars") and a lower share of people engaged in manual labor ("blue collars").
} 


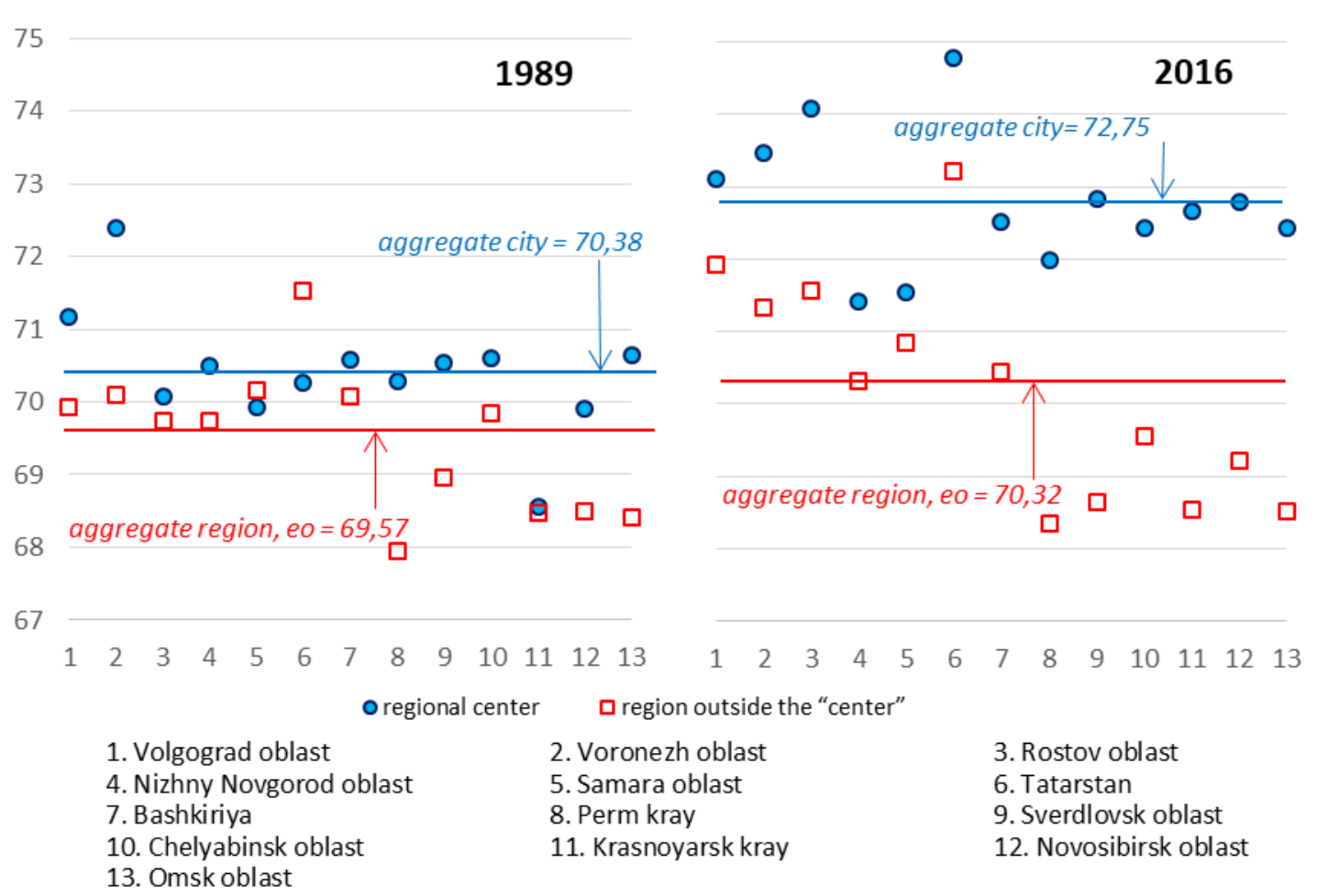

Figure 3. Life expectancy at birth in million-plus cities, in the rest of their regions, in the aggregate city and the aggregate region in 1989 and 2016, years

Possible reasons for the gap in life expectancy between million-plus cities and their surrounding territories include: different levels of socio-economic development and different professional and educational compositions of the population, inequality in access to modern medical technologies, and selection as a result of migration. The large gap in life expectancy might also be influenced by other factors determined by the settlement structure of a particular region: the degree of urbanization, the proportion of the population living in the agglomeration belt of the administrative center, and the presence of other large urban centers. The greatest differences in life expectancy between the "center" and the "periphery" in 2016 were observed in the regions of the Urals (Sverdlovsk and Chelyabinsk oblasts, Perm kray) and Siberia (Novosibirsk and Omsk oblasts, Krasnoyarsk kray), while the minimum difference, as in 1989, was recorded in the Volga region (Samara and Nizhny Novgorod oblasts).

\section{DISCUSSION}

Life expectancy at birth in most million-plus cities since the late 1990s has been higher than in the rest of Russia. At the same time, no other Russian million-plus city since the beginning of the 21 st century has shown the same dynamics and indicators of mortality as Moscow, which confirms its unique position on the "mortality map" of Russia. How can we explain the differences in mortality between million-plus cities and the rest of the country, as well as between Moscow and other major Russian cities? We will focus our attention on two factors: the level of economic development (as a proxy indicator of the standard of living) and the educational structure of the population.

The relationship between life expectancy at birth and the level of economic development, expressed in terms of gross domestic product (GDP) per capita, is described at the level of 
individual territories (usually states) by the so-called Preston curve, which shows a strong connection between these two indicators [Preston 2007]. However, Russia, both at the level of the whole country (where life expectancy at birth, on the basis of GDP per capita, should be significantly higher than observed) and at the regional level (there is no connection between longevity and economic indicators in our country) does not follow this pattern [Andreev, Shkolnikov 2018]. At the same time, our country is characterized by a strong polarization of the economic space, including at the subregional level. Thus, in 2015, thirteen non-capital cities with a population of more than one million people comprised $37 \%$ of the total population of the regions whose administrative centers they are, while they produced $48 \%$ of the total gross regional product (GRP) of these regions (Appendix 7). In 2015, GRP per capita in eleven of the thirteen regions considered was higher in the center than in the rest of the region (by $1.4-3.2$ times); only in Tatarstan (oil production and refining) and the Krasnoyarsk Kray (Norilsky Nickel, Vankor oil and gas field) the reverse situation was observed. On average, GRP per capita in million-plus cities was 1.6 times higher than in the residual areas of their regions.

Figure 4 (left graph) shows that in 2015 the highest GRP per capita, significantly higher than in other million-plus cities and the rest of Russia, was recorded in Moscow; the same is true for life expectancy at birth. In addition, the gross urban product per capita (GUP) was greater in all million-plus cities than in the rest of the country, as was life expectancy. At the same time, without taking Moscow into account, there was no connection at the level of million-plus cities between the gross urban product per capita and life expectancy at birth.

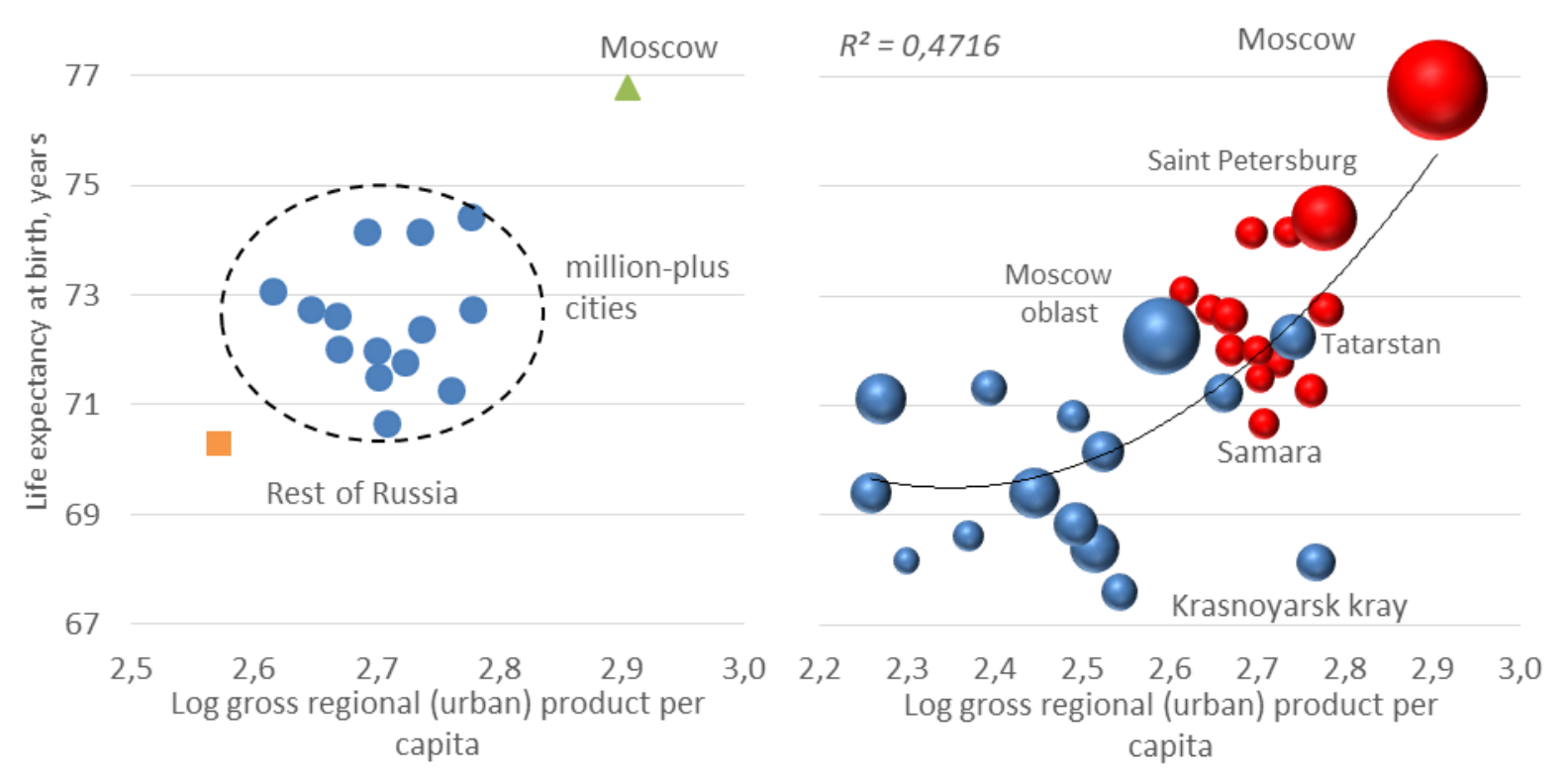

Figure 4. Relationship between life expectancy at birth and gross urban (regional) product per capita (in PPP) in Russian cities with a population of one million or more (red), the rest of their regions (blue) and the rest of Russia, 2015

In the right graph (Figure 4) one can observe, in addition to million-plus cities, GRP per capita and life expectancy at birth in regions whose administrative centers are million-plus cities, but excluding the latter, i.e. in the rest of the territory of the respective regions. The diameter of the circle on the graph is directly proportional to the population size of the region. As on the left graph, on the right graph one can see that there is a direct connection between GRP per capita and 
life expectancy at birth, and this despite the fact that the gross regional product as an indicator of the level of economic development is not without drawbacks (the share of the economy attributable to small business, on which it is harder to gather statistics, as well as the share of the shadow economy, can vary greatly between regions). On the other hand, a high level of economic development is not always translated into good health of the population. A good example is the Krasnoyarsk kray outside the regional capital, where a very high GRP per capita is combined with a very low life expectancy. However, in general, it seems to us that at the subregional level in Russia the economic polarization (inequality) between the central cities and the rest of the territory of the respective regions and the resulting difference in the standard of living can serve as one of the explanations for the existing central-peripheral gap in the health (mortality) of the population.

Due to a higher level of economic development (and therefore a higher standard of living), almost all million-plus cities in Russia are centers of attraction for internal and external migrants, who, as a rule, due to selectivity (in order to move to another city and gain a foothold there, one generally requires good health) have lower mortality rates compared with both the host population and the population of the places from which migrants originate [Razum, Zeeb, Rohrmann 2000: 191-192; Marmot, Adelstein, Bulusu 1984: 1455-1457]. This is especially pronounced in Russia at the subregional level (and, in the case of Moscow and St. Petersburg, also at the interregional level), when the most goal-oriented, educated and, most importantly, healthy people from the periphery tend to move to the capital or regional center, while the less educated and ambitious are not inclined to migrate. All this leads to a negative selection for health in the periphery and to a positive one in the administrative center of the region. This undoubtedly contributes to the strengthening of the central-peripheral inequality in mortality in Russia.

One of the most important factors affecting the mortality rate is educational level. Numerous studies, including in Russia, show that people with higher levels of education live longer than those with lower levels [Shkolnikov et al. 2004; Kharkov, Nikitina, Andreev 2017; Pyankova, Fattakhov 2017]. An educational gradient is also observed in infant mortality (depending on the educational status of the mother) [Cochrane, Ohara, Leslie 1980: 95; Kvasha 2008]. Considering that almost all million-plus cities in Russia since Soviet times have been large university centers (in their regions, the largest and sometimes the only ones), and that the majority of non-resident students tend to remain in the place where they obtained their degrees (and, if they want to move, will go to an even larger city, usually to the capital or abroad), it is easy to suppose that in the largest cities of the country, compared with the rest of Russia, a greater share of the population has a higher education, which could also explain to a significant degree the differences between them in mortality. To test this hypothesis, we turned to the 2010 All-Russian Population Census, which contained a question about the level of education. We calculated the standardized (by one-year age groups, where the standard was the age structure of the Russian population according to the 2010 census) proportion of people over the age of 30 (the age after which the educational level of a person changes very rarely) with higher education for all million-plus cities, as well as for the remaining populated areas of regions whose administrative centers are millionplus cities, and for the rest of Russia, the aggregate city and the aggregate region. Those who did not indicate the level of education were distributed proportionally among all educational groups. The results are presented in Figure 5. 

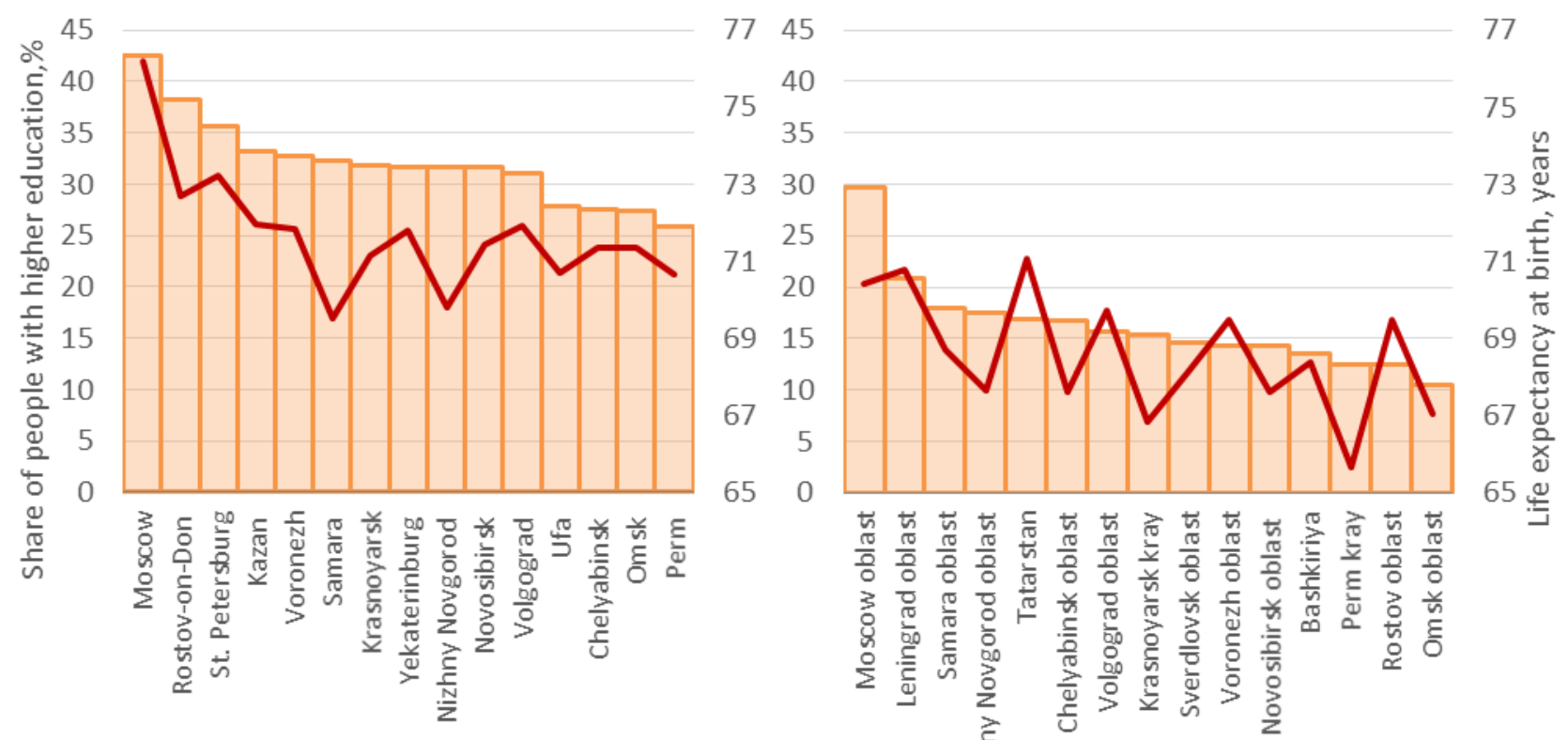

$\square$ Proportion of people in the population over 30 years old with higher education (2010)

Life expectancy at birth (2011)

Figure 5. The proportion of people in the population over 30 years old with higher education (left scale) and life expectancy at birth in 2011 (right scale) in Russian cities with a population of over one million people and the rest of the territory of the respective regions

Indeed, million-plus cities in Russia are notable for a greater proportion of people with higher education (31\% in the aggregate city, which, we recall, does not include Moscow and St. Petersburg, versus only $15.5 \%$ in the aggregate region and $19.6 \%$ for the rest of Russia). Moscow, in turn, as with GUP per capita, has a significantly greater proportion of people with higher education than other million-plus cities. Interestingly, in second place came Rostov-on-Don, not St. Petersburg, which ranked third. The Rostov region also recorded the largest gap in the educational level between the center and the rest of the region. We also note that in the population of the Moscow region, the proportion of people who graduated from high school (almost 30\%) is higher than in four out of fifteen million-plus cities, while in the Omsk region outside Omsk only one out of ten people has a higher education.

Figure 6 shows three distinct clusters - Moscow, the other million-plus cities, including St. Petersburg, and their regions outside the center - differing from each other in terms of the proportion of people over 30 years of age with higher education and life expectancy at birth. At the same time, the relationship between educational structure and mortality is much stronger than between mortality and the level of economic development. In two cities - Samara and Nizhny Novgorod - life expectancy at birth is significantly lower than might be expected based on their educational structure (a high proportion of people with higher education). Perhaps in these cities the proportion of people with a very low level of education is higher than in others, and in the case of Samara it is worth noting that of all the million-plus cities it has the highest rate of mortality from HIV as well as from external causes [Schur 2018: 109] Interestingly, if for million-plus cities the level of education is quite strongly correlated with life expectancy at birth, then for their areas outside the center this factor does not matter much; far more important is the geographical factor 
(south-west/north-east mortality gradient) and possibly also the ethnic one (in the case of Tatarstan and to a lesser extent Bashkiriya).

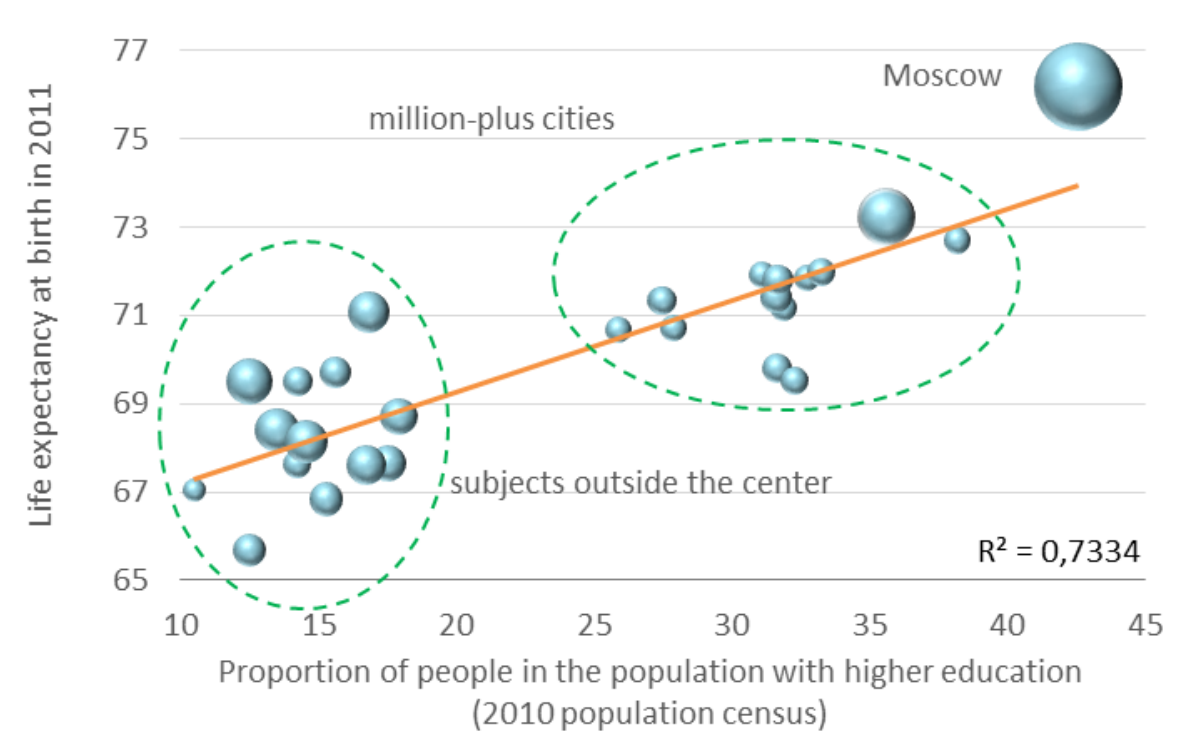

Figure 6. Relationship between life expectancy at birth and the proportion of people in the population with higher education in Russian cities with a population of over one million and in their areas outside the center

When explaining the higher level of life expectancy at birth in cities with a population of over 1 million, one should not ignore access to health care, especially involving modern medical technologies, which, due to population density and logistics (infrastructure), is significantly greater in the major agglomerations than in the areas outside them. As an example, if in million-plus cities the whole population lives within a one-hour ride from a $\mathrm{PCI}^{9}$ center, then for Russia as a whole this figure is only 45\% [Timonin et al. 2018]. It seems that geographical inequality in the level of accessibility of modern medicine is precisely what is most easily affected by government actors, while other (structural) factors, such as differences in the level of economic development or educational structure, as well as the central-peripheral direction of migration flows, are much harder to change, and their influence can hardly be completely eliminated.

\section{CONCLUSION}

Over the decades following the collapse of the Soviet Union the level of inequality in mortality between Russian million-plus cities and the rest of Russia has increased significantly. Standing apart from them all is Moscow, whose life expectancy at birth began in the 2000s to significantly outpace other Russian million-plus cities. St. Petersburg occupies an intermediate position between the capital and the "provincial" million-plus cities, among which, in turn, in the 2000s stand out both the group of "leaders" (Kazan and Rostov-on-Don) and the group of "laggards" (Nizhny Novgorod and Samara). Differentiation of million-plus cities in terms of life expectancy is not determined by their level of economic development (expressed in terms of gross urban

\footnotetext{
${ }^{9} \mathrm{PCI}$ - percutaneous coronary intervention (in other words, stenting) is the most effective way to treat acute coronary heart disease.
} 
product per capita), size (population) or geographic coordinates; however, one can see some connection between the educational level of a city's population (the proportion of people over 30 years with higher education) and life expectancy in it.

The life expectancy gap between million-plus cities and "their" regions not only increased significantly in 1989-2016 (on average, by almost 2 years), but, as a rule, increased relative to the rest of the country, too, i.e. Russia's central-peripheral inequality in mortality is more pronounced at the sub-regional level. Interestingly, the southwest/northeast mortality gradient, relatively unimportant at the level of million-plus cities, is a good predictor of differences in life expectancy in their areas outside the "centers". Thus, the maximum level of central-peripheral inequality in mortality is observed in the regions of the Urals and Siberia, where there is a very low life expectancy outside the regional capitals, while in the regions of the European part of Russia the difference between "centers" and "periphery" is significantly smaller (with the exception of the Moscow metropolitan region). The main cause of central-peripheral inequality in mortality in Russia, it seems to us, is excessive centralization both at the country level and at the level of individual regions, leading to the concentration in the regional centers of most of the human capital of the entire region, and in Moscow - of the entire country.

\section{ACKNOWLEDGMENTS}

The author thanks E.M. Andreev, S.A. Timonin, T.L. Kharkova and V.M. Shkolnikov for valuable advice and assistance in preparing this article.

\section{REFERENCES}

Andreev E., V.M. Shkolnikov, T. Valkonen, A. Begun (2001). Measuring inter-group inequalities in length of life // Genus. 57(3-4): 33-62.

Andreev E.M. (1979). Prodolzhitel'nost' zhizni v SSSR: differentsial'nyy analiz [Life expectancy in the USSR: differential analysis] // Prodolzhitel'nost' zhizni: analiz i modelirovanie [Lifespan: Analysis and Modeling]. Moscow: Statistika: 7-31.

Andreev E.M. (2012). O tochnosti rezul'tatov rossiyskikh perepisey naseleniya i stepeni doveriya $\mathrm{k}$ raznym istochnikam informatsii [On the accuracy of the results of Russian population censuses and the level of confidence in different sources of information] // Voprosy statistiki [Issues of Statistics]. 11: 21-35.

Andreev E.M., E.A. Kvasha, T.L. Kharkova (2006). Osobye tochki na karte smertnosti [The special points on the map of mortality] // Naselenie Rossii 2003-2004 [Population of Russia 2003-2004]. Odinnadtsatyy-dvenadtsatyy ezhegodnyy demograficheskiy doklad [Eleventhtwelfth annual demographic report] / A.G. Vishnevsky, ed. Moscow: 298-305.

Andreev E.M., E.A. Kvasha, T.L. Kharkova (2016). Smertnost' v Moskve i drugikh megapolisakh mira: skhodstva i razlichiya [Mortality in Moscow and other megacities of the world: similarities and differences] // Demograficheskoe obozrenie [Demographic Review]. 3(3): 39-79.

Andreev E.M., V.M. Shkolnikov (2018). Svyaz' mezhdu urovnyami smertnosti i ekonomicheskogo razvitiya v Rossii i ee regionakh [The relationship between mortality and 
economic development in Russia and its regions] // Demograficheskoe obozrenie [Demographic Review]. 5(1): 6-24.

Cochrane SH., DJ. Ohara, J. Leslie (1980). The effects of education on health. Washington, D.C., World Bank. 95 p. (World Bank Staff Working Paper №405.)

Demograficheskaya situatsiya v Moskve i tendentsii ee razvitiya [The demographic situation in Moscow and its development trends] (2006) / L.L. Rybakovsky, ed. Moscow: TsSP. 264 p.

Eberstadt N. (1981). The health crisis in the USSR // New York Review Books: 23-21. (Reprinted Int J Epedemiol 2006; 35:1384-94.)

Grigoriev P., F. Meslé, V.M. Shkolnikov, E. Andreev, A. Fihel, M. Pechholdova et al. (2014). The recent mortality decline in Russia: Beginning of the cardiovascular revolution? // Population and Development Review. 40(1): 107-129.

Grigoriev P., G. Doblhammer-Reiter, V.M. Shkolnikov (2013). Trends, patterns, and determinants of regional mortality in Belarus, 1990-2007 // Population Studies-A Journal of Demography. 67: 61-81.

Kalediene R., J. Petrauskiene (2000). Regional life expectancy patterns in Lithuania // European Journal of Public Health. 10(2):101-104.

Kalediene R., J. Petrauskiene (2004). Socio-economic transition, inequality, and mortality in Lithuania // Economics and Human Biology. 2(1):87-95.

Kharkova T.L., S.Yu. Nikitina, E.M. Andreev (2017). Zavisimost' prodolzhitel'nosti zhizni ot urovnya obrazovaniya $v$ Rossii [The dependence of life expectancy on the level of education in Russia] // Voprosy statistiki [Issues of Statistics]. 8: 61-68.

Krumins J., D. Jasilionis, L. Mall, V. Stankuniene (2009). Changes of geographical mortality differences in the three Baltic countries during the period of socio-economic transformation. Paper presented at the IUSSP 26th International Population Conference, Marrakech.

Kvasha E.A. (2008). Differentsiatsiya mladencheskoy smertnosti po urovnyu obrazovaniya materi v regionakh Rossii v kontse 80-kh - seredine 90-kh godov 20 veka [Differentiation of infant mortality by the level of education of the mother in the regions of Russia in the late 80s - mid 90s of the 20th century] // Demoscope Weekly. 331-332.

URL:http://www.demoscope.ru/weekly/2008/0331/analit06.php (accessed: 04.11.2018).

Kvasha E.A., T.L. Kharkova (2009). Rossiyane i moskvichi ne ravny pered litsom smerti [Russians and Muscovites are not equal in the face of death] // Demoscope Weekly. 369-370. URL: http://demoscope.ru/weekly/2009/0369/tema01.php (accessed: 04.11.2018).

Marmot M.G., A.M. Adelstein, L. Bulusu (1984). Lessons from the study of immigrant mortality // Lancet. 2: 1455-1457.

Mkrtchyan N.V. (2012). Problemy ucheta naseleniya otdel'nykh vozrastnykh grupp v khode perepisi naseleniya 2010 g.: prichiny otkloneniy poluchennykh dannykh ot ozhidaemykh [Problems of registration of the population of certain age groups during the 2010 census: reasons for deviations of the data from the expected] // Demograficheskie aspekty sotsial'noekonomicheskogo razvitiya [Demographic aspects of socio-economic development]. Iss. 22. I M.B. Denisenko, ed. Moscow: MAKS Press: 197-214.

Neravenstvo i smertnost' v Rossii [Inequality and Mortality in Russia] (2000) / V.M. Shkolnikov, E.M. Andreev, T.M. Maleva, eds. Moscow: Signal. 123 p.

Papanova E.K., V.M. Shkolnikov, E.M. Andreev, S.A. Timonin (2017). Vysokaya prodolzhitel'nost' zhizni moskvichey posle 80 let - real'nost' ili statisticheskiy artefakt? [High 
life expectancy of Muscovites after 80 years - a reality or a statistical artifact?] // Uspekhi gerontologii [Advances in gerontology]. 6: 826-835.

Preston S.H. (2007). The changing relation between mortality and level of economic development // International Journal of Epidemiology. 36 (3): 484-90.

P'yankova A.I., T.A. Fattakhov (2017). Smertnost' po urovnyu obrazovaniya v Rossii [Mortality by level of education in Russia] // Ekonomicheskij zhurnal VSHE [HSE Economic Journal]. 21(4): 623-647.

Razum O., H. Zeeb, S. Rohrmann (2000). The 'healthy migrant effect'-not merely a fallacy of inaccurate denominator figures // International Journal of Epidemiology. 29(1):191-192.

Semenova V.G. (2005). Obratnyy epidemiologicheskiy perekhod v Rossii [Reverse epidemiological transition in Russia] (2005). Moscow. 235 p.

Shchur A. (2018). Tendentsii smertnosti v rossiyskikh gorodakh s chislennost'yu naseleniya svyshe odnogo milliona chelovek (1989-2016 gg.) [Mortality trends in Russian cities with a population of over one million people (1989-2016)]: master thesis. Moscow: NRU HSE.

Shkaratan O.I. (2009). Sotsial'no-ekonomicheskoe neravenstvo i ego vosproizvodstvo v sovremennoy Rossii. [Socio-economic inequality and its reproduction in modern Russia] Moscow: Olma Media Grupp. 556 p.

Shkolnikov V.M. (1987). Geograficheskie faktory prodolzhitel'nosti zhizni [Geographical factors of life expectancy] // Izvestiya AN SSSR. Seriya Geograficheskaya [News of the USSR Academy of Sciences. Geographical series]. 3(12): 35-44.

Shkolnikov V.M., E. Andreev, D. Jdanov, J. Vallin, F. Meslé, C. Boe, J. Wilmoth, S. GellersBarkmann (2017). Methodology note for the Life Table Database (LTDB). URL: http://www.lifetable.de/methodology.pdf (accessed: 05.11.2018).

Shkolnikov V.M., A.D. Deev, Ø. Kravdal, T. Valkonen (2004). Educational differentials in male mortality in Russia and northern Europe. A comparison of an epidemiological cohort from Moscow and St. Petersburg with the male populations of Helsinki and Oslo // Demographic research. 10(1): 1-26.

Shkolnikov V.M., E. Andreev, D. Jasilionis, M. Leinsalu, O. Antonova, M. McKee (2006). The changing relation between education and life expectancy in central and eastern Europe in the 1990s // Journal of Epidemiology and Community Health. 60(10): 875-881.

Shkolnikov V.M., E. Andreev, M. McKee, D.A. Leon (2013). Components and possible determinants of decrease in Russian mortality in 2004-2010 // Demographic Research. 28(32): 917-950.

Shkolnikov V.M., G.A. Cornia, D.A. Leon, F. Meslé (1998). Causes of the Russian mortality crisis: evidence and interpretations // World Development. 26(11): 1995-2011.

Shkolnikov V.M., S. Vasin (1994). Spatial differences in life expectancy in European Russia in the 1980s. // Demographic trends and patterns in the Soviet Union before 1991 / W. Lutz, S. Scherbov, A. Volkov, eds. London: Routledge: 379-402.

Timonin S., A. Kontsevaya, M. McKee, D.A. Leon (2018). Reducing geographic inequalities in access times for acute treatment of myocardial infarction in a large country: the example of Russia // International Journal of Epidemiology. 47(5): 1594-1602.

Timonin S., I. Danilova, E. Andreev, V.M. Shkolnikov (2017). Recent mortality trend reversal in Russia: are regions following the same tempo? // European Journal of Population. 33(1): 733 763. 
Vallin J., E. Andreev, F. Meslé, V.M. Shkolnikov (2005). Geographical diversity of cause-ofdeath patterns and trends in Russia // Demographic Research. 12(13): 323-380.

Vasin, S., C.A. Costello (1997). Spatial, age, and cause-of-death patterns of mortality in Russia, 1988-1989 // Premature Death in the New Independent States / J.L. Bobadilla, C.A. Costello, F. Mitcell, eds. Washington, DC: National Academies Press: 66-119.

Vishnevsky A., Shkolnikov V. (1997). Smertnost' v Rossii: glavnye gruppy riska i prioritety deystviya (Mortality in Russia: main risk groups and priorities of action). Nauchnye doklady Moskovskogo Tsentra Karnegi (Scientific reports of the Moscow Carnegie Center), Issue 19. Carnegie Endowment for International Peace: 83 p.

Vishnevsky A. (2015). Mortality in Russia: the second epidemiological revolution that never was // Demographic Review, English selection: 4-33.

Walberg P., M. McKee, V.M. Shkolnikov, L. Chenet, D.A. Leon (1998). Economic change, crime and Russian mortality crisis: a regional analysis // British Medical Journal. 317(7154): 312-318. (accessed: 10.08.2018).

Zubarevich N.V. (2010). Goroda kak tsentry modernizatsii ekonomiki i chelovecheskogo kapitala [Cities as centers of economic modernization and human capital] // Obshchestvennye nauki i sovremennost [Social Sciences and Contemporary World]. 5: 5-19. 


\section{APPENDIX}

\section{Appendix 1. Mid-year population estimates in Russian million-plus cities, except for Moscow and Saint Petersburg, 1989-2016, in thousand people}

\begin{tabular}{|l|l|l|l|l|l|l|l|l|l|l|l|l|l|l|l|l|l|l|l|l|l|l|l|l|l|l|}
1999 & 1990 & 1991 & 1992 & 1993 & 1994 & 1995 & 1996 & 1997 & 1999 & 2000 & 2001 & 202 & 2003 & 2004 & 2005 & 200 & 2007 & 2008 & 2009 & 2010 & 2011 & 2012 & 2013 & 2014 & 2015 & 2016 \\
\hline
\end{tabular}

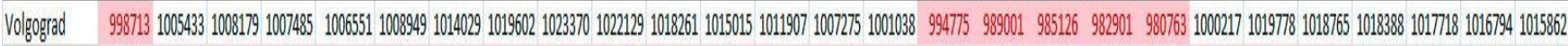

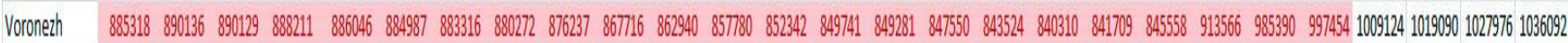

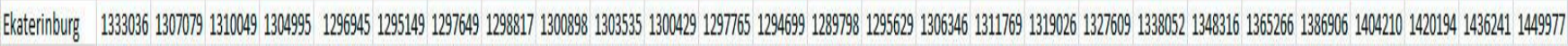

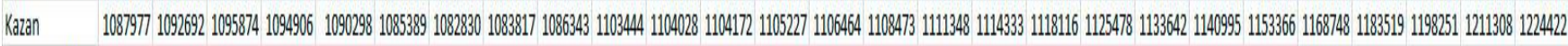

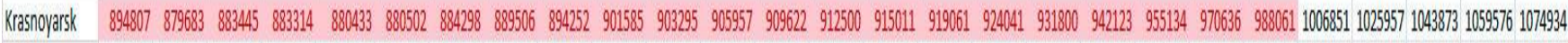

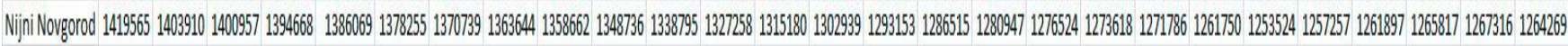

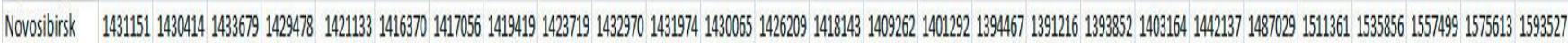

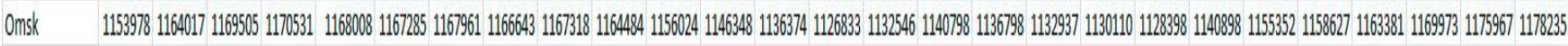

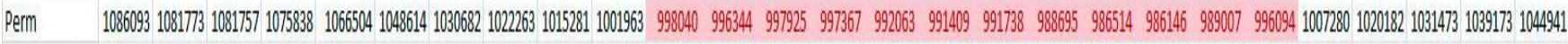

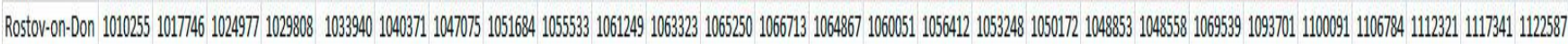

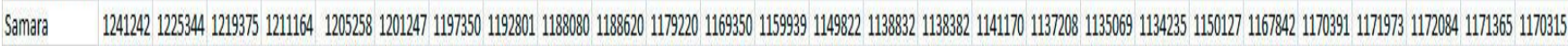

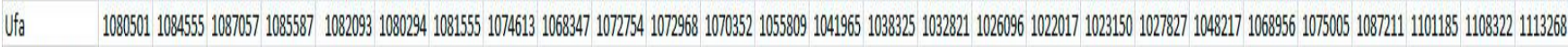

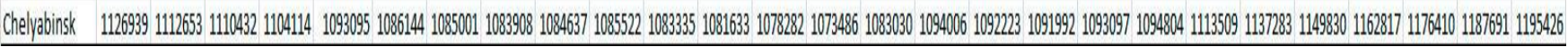

Appendix 2. Combined population on the 1st of January of each year of Russian millionplus cities, except for Moscow and Saint Petersburg

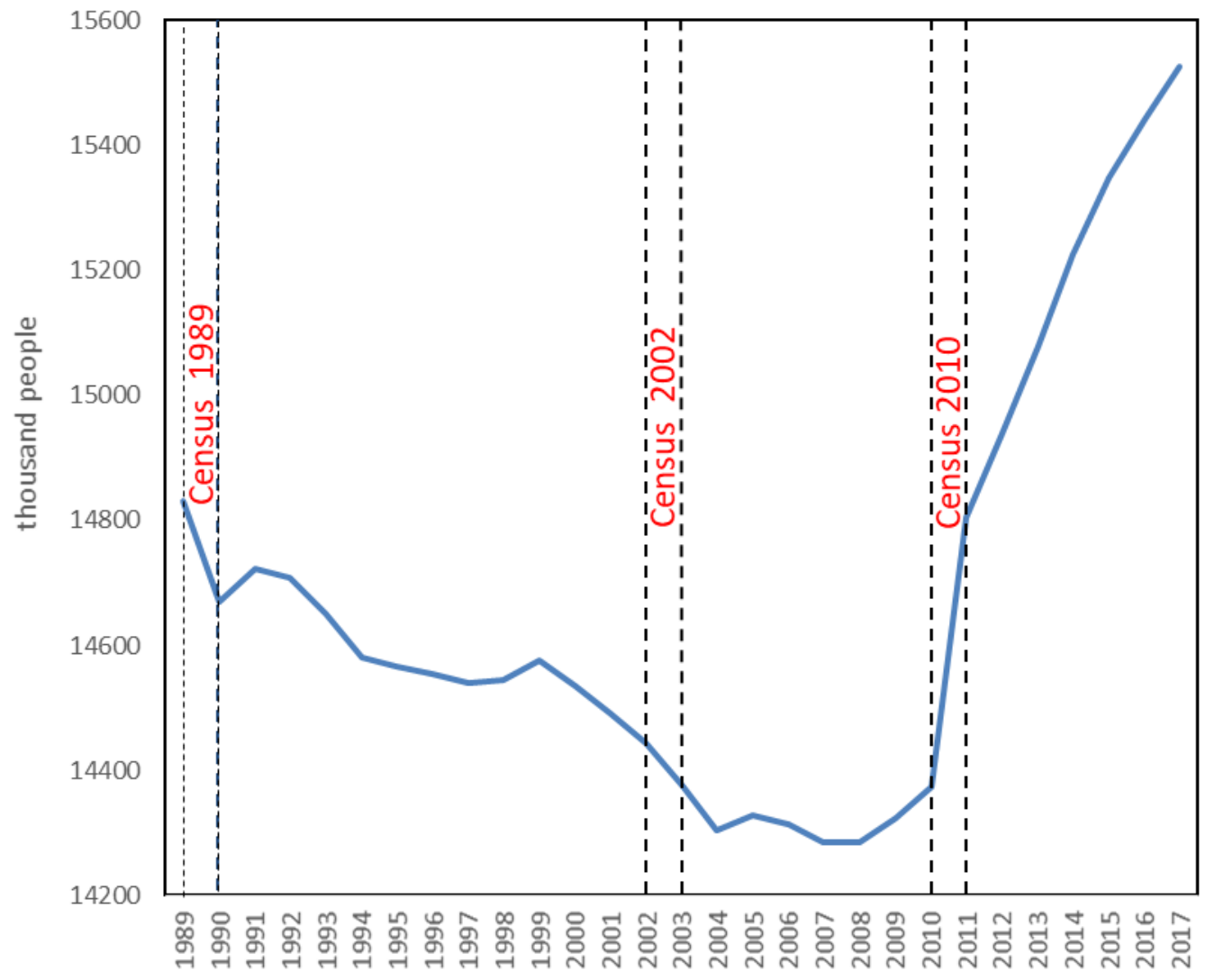


Appendix 3. Mortality curves $(\log M x)$ at the ages 80+ in Moscow, Saint Petersburg, the aggregate million-plus city and Sweden (as a country with some of the highest quality data on mortality)

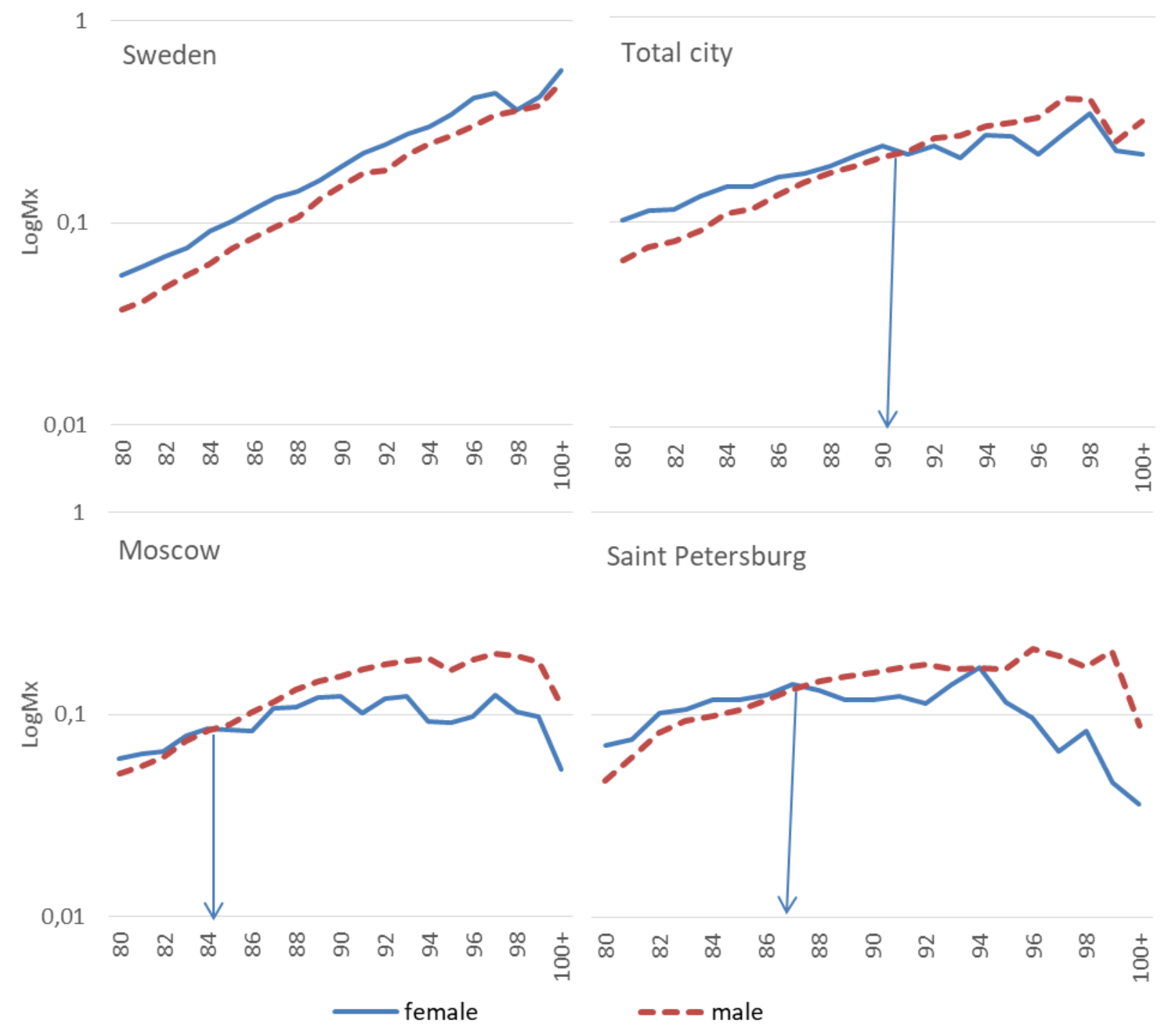




\section{Appendix 4. Life expectancy at birth in Russian million-plus cities, 1989-2016}

\section{Males}

\begin{tabular}{|c|c|c|c|c|c|c|c|c|c|c|c|c|c|c|c|c|c|c|c|c|c|c|c|c|c|c|c|}
\hline & 1989 & 1990 & 1991 & 1992 & 1993 & 1994 & 1995 & 1996 & 1997 & 1999 & 2000 & 2001 & 2002 & 2003 & 2004 & 2005 & 2006 & \begin{tabular}{|l|}
2007 \\
\end{tabular} & 2008 & 2009 & 2010 & 2011 & 2012 & 2013 & 2014 & 2015 & 2016 \\
\hline /olgo & 66,3 & 66,5 & 66,2 & 65,0 & 62,3 & 60,0 & 60,6 & 62,0 & 62,5 & 61,3 & 60,7 & 60,5 & 60,5 & 60,8 & 62,0 & 61,9 & 62,7 & 64,3 & 64,7 & 65,2 & 65,3 & 66,0 & 66,3 & 67,3 & 66,9 & 67,7 & 68,0 \\
\hline /oronezh & 67,4 & 67,9 & 66,6 & 66,0 & 63,4 & 61,9 & 61,7 & 63,4 & 64,8 & 62,1 & 61,2 & 60,4 & 60,3 & 60,2 & 60,3 & 60,6 & 60,9 & 61,3 & 62,8 & 64,2 & 64,5 & 65,6 & 66,2 & 66,2 & 65,5 & 66,5 & 67,1 \\
\hline & 5,7 & 5,0 & 64,6 & 62,1 & 58,6 & 58,1 & 58,9 & 60,2 & 62,2 & 60,6 & 59,0 & 59,6 & 60,0 & 59,8 & 60,3 & 61,0 & 62,4 & 63,3 & 63,5 & 64,6 & 65,4 & 66,0 & 66,1 & 66,5 & 66,5 & 66,8 & 7,0 \\
\hline azan & 64,8 & 64,5 & 64,7 & 64,0 & 61,5 & 59,6 & 59,3 & 61,9 & 62,1 & 61,5 & 60,5 & 60,6 & 60,7 & 60,7 & 59,9 & 60,6 & 62,4 & 63,6 & 64,7 & 65,7 & 64,4 & 65,8 & 66,7 & 67,4 & 67,5 & 68,4 & 69,4 \\
\hline 'rasnoyé & 62,9 & 62,0 & 61,3 & 59,2 & 54,7 & 53,7 & 54,4 & 56,3 & 58,8 & 57,4 & 56,3 & 57,5 & 58,0 & 58,3 & 59,5 & 58,9 & 61,6 & 62,2 & 63,7 & 64,6 & 64,7 & 65,2 & 65,3 & 66,2 & 65,9 & 66,9 & 66,7 \\
\hline loscon & 5,0 & 4,8 & 4,9 & 3,4 & 59,5 & 7,7 & 58,9 & 2,4 & 4,5 & & 64,5 & 64,4 & 64,9 & 65,0 & 5,9 & 6,7 & 7,3 & 3,2 & 68,7 & 69,7 & 70,0 & 1,5 & 1,6 & 2,3 & 2,8 & 3,0 & 73,5 \\
\hline ijni I & 64,9 & 4,8 & 65,1 & 63,2 & 59,7 & 56,9 & 57,0 & 60,4 & 62,1 & 61,2 & 59,7 & 59,6 & 58,8 & 58,0 & 58,3 & 58,4 & 58,8 & 60,0 & 60,4 & 61,6 & 61,3 & 63,3 & 63,1 & 64,0 & 64,3 & 65,0 & 65,0 \\
\hline Vovosibirsk & 64,6 & 64,2 & 64,8 & 63,4 & 58,6 & 57,0 & 59,6 & 60,7 & 62,4 & 62,5 & 61,7 & 60,9 & 60,8 & 60,1 & 60,1 & 59,4 & 61,1 & 62,1 & 63,5 & 64,6 & 65,0 & 65,5 & 65,3 & 66,0 & 66,1 & 66,7 & 66,9 \\
\hline msk & 5,6 & 6,6 & 65,7 & 64,7 & 61,6 & 59,9 & 61,0 & 62,0 & 62,3 & 61,6 & 60,5 & 61,2 & 60,7 & 60,1 & 60,2 & 59,1 & 60,3 & 61,3 & 62,7 & 64,2 & 64,4 & 65,4 & 65,2 & 65,4 & 65,5 & 66,0 & 6,5 \\
\hline Perm & & & & 63,2 & 59,7 & 57,7 & 57,5 & 59,3 & & & 58,9 & 58,9 & 59,2 & 58,7 & 58,5 & & 60,9 & 62,3 & 62,4 & 62,9 & 63,3 & 64,3 & 64,8 & 65,4 & 5,4 & 5,3 & 66,1 \\
\hline lostov & 65,4 & 64,7 & 64,3 & 63,6 & 60,9 & 59,5 & 59,4 & 61,4 & 63,4 & 63,9 & 62,3 & 61,9 & 61,7 & 62,0 & 62,9 & 63,4 & 63,6 & 65,1 & 65,8 & 66,9 & 67,2 & 67,6 & 68,3 & 69,1 & 68,5 & 69,6 & 69,7 \\
\hline Samara & 64,6 & 64,0 & 64,2 & 62,7 & 59,9 & 58,0 & 58,5 & 58,8 & 61,1 & 58,8 & 56,8 & 57,2 & 59,0 & 58,9 & 58,6 & 59,6 & 60,3 & 60,6 & 61,1 & 61,8 & 61,7 & 63,1 & 63,8 & 63,4 & 63,2 & 64,4 & 65,7 \\
\hline Saint Petersburg & 65,6 & 64,7 & 64,3 & 62,4 & 57,5 & 57,4 & 59,6 & 62,5 & 64,4 & 62,0 & 60,4 & 60,7 & 61,1 & 61,0 & 61,1 & 61,7 & 63,1 & 64,3 & 65,2 & 66,3 & 66,8 & 67,8 & 68,4 & 69,4 & 69,8 & 69,8 & 70,3 \\
\hline Jfa & 65,6 & 6,5 & 65,3 & 4,7 & 61,5 & 60,0 & 60,5 & 62,5 & 63,5 & 62,2 & 61,4 & 61,6 & 61,2 & 60,7 & 60,8 & & 62,6 & 63,1 & 63,7 & 65,4 & 64,8 & 65,0 & 5,3 & 65,6 & 65,3 & 65,7 & 66,7 \\
\hline Chelyabinsk & 65,5 & 65,6 & 65,8 & 63,5 & 60,2 & 58,2 & 58,3 & 60,6 & 62,6 & 61,4 & 59,9 & 60,1 & 60,0 & 60,0 & 60,4 & 60,1 & 61,7 & 63,6 & 63,5 & 64,4 & 64,6 & 65,2 & 65,2 & 65,3 & 65,4 & 65,8 & 66,2 \\
\hline
\end{tabular}

\section{Females}

\begin{tabular}{|c|c|c|c|c|c|c|c|c|c|c|c|c|c|c|c|c|c|c|c|c|c|c|c|c|c|c|c|}
\hline & 1989 & 1990 & 1991 & 1992 & 1993 & 1994 & 1995 & 1996 & 1997 & 1999 & 2000 & 2001 & 2002 & 2003 & 2004 & 2005 & 2006 & 2007 & 2008 & 2009 & 2010 & 2011 & 12012 & $\begin{array}{ll}2 & 2013 \\
\end{array}$ & 2014 & 2015 & 2016 \\
\hline Volgograd & 5,5 & 75,4 & 75,5 & 75,5 & 73,9 & 72,5 & 72,7 & 73,9 & 74,3 & 73,5 & 73,8 & 73,5 & 73,9 & 73,4 & 74,4 & 74,3 & 375,0 & 75,8 & 76,4 & 76,7 & 76,2 & 77,4 & 477,6 & 677,6 & 78,2 & 77,9 & 78,4 \\
\hline Voro & & 76,7 & & 76,2 & 74,6 & 74,8 & 74,8 & 75,2 & 75,2 & & & & 74,1 & 73,5 & 74,2 & 74,0 & & 75,1 & 75,4 & 75,8 & 76,5 & 77,6 & 677,8 & 878,2 & 78,2 & 78,6 & 78,7 \\
\hline & & 4,0 & & & 71,6 & 70,8 & 71,6 & 72,7 & & & & 73,3 & 72,9 & 73,0 & 74,2 & 74,0 & 74,7 & 75,5 & 75,6 & 76,0 & 76,8 & 76,9 & 976,8 & 877,9 & 77,5 & 77,9 & 77,9 \\
\hline Kazan & 75,0 & 5,2 & 75,2 & 75,5 & 74,4 & 73,2 & 73,2 & 74,3 & 74,5 & 74,6 & 74,1 & 74,2 & 74,4 & 74,4 & 74,6 & 74,8 & 375,5 & 56,1 & 76,5 & 76,9 & 76,6 & 77,5 & 578,4 & 478,5 & 78,5 & 79,1 & 79,3 \\
\hline Krasnoy & 3,5 & 73,1 & 72,7 & 72,4 & 69,5 & 68,6 & 70,3 & 70,9 & 71,3 & 70,9 & 71,3 & 72,0 & 71,8 & 72,0 & 72,9 & 72,9 & 9 74,1 & 74,6 & 74,9 & 75,6 & 76,0 & 76,5 & 576,4 & 477,0 & 77,4 & 77,1 & 77,9 \\
\hline Moscow & 4,2 & 74,1 & 74,2 & 74,0 & 72,1 & 71,5 & 72,1 & 73,8 & 74,3 & 74,7 & 75,0 & 74,7 & 74,8 & 75,0 & 75,8 & 76,3 & 376,9 & 77,5 & 77,8 & 78,5 & 78,2 & 79,8 & B 79,6 & 680,2 & 80,4 & 80,4 & 80,4 \\
\hline Nijni Nov & 75,5 & 74,8 & 75,1 & 74,8 & 72,7 & 71,6 & 71,4 & 72,8 & 73,9 & 73,6 & 73,0 & 73,0 & 72,5 & 72,3 & 72,3 & 72,3 & 373,5 & 73,7 & 74,5 & 75,1 & 74,2 & 75,8 & 8 75,8 & 876,5 & 76,5 & 76,9 & 77,1 \\
\hline Novosibirsk & 74,5 & 74,6 & 74,5 & 74,0 & 71,5 & 70,8 & 72,4 & 73,0 & 73,8 & 74,1 & 74,1 & 73,9 & 73,1 & 73,4 & 73,7 & 73,4 & 475,0 & 75,3 & 75,8 & 76,2 & 76,6 & 76,9 & 977,1 & 177,4 & 77,5 & 78,2 & 78,2 \\
\hline Omsk & 75,0 & 75,9 & 75,6 & 75,5 & 73,6 & 72,7 & 73,2 & 73,8 & 74,0 & 74,0 & 73,4 & 73,7 & 73,0 & 72,9 & 73,3 & 73,3 & 374,0 & 74,2 & 75,2 & 75,6 & 75,9 & 76,8 & 876,6 & 577,1 & 77,5 & 77,6 & 77,9 \\
\hline Perm & 74,4 & 74,4 & 74,0 & 73,4 & 71,2 & 70,7 & 70,6 & 71,7 & 73,2 & 72,0 & 72,6 & 72,5 & 72,3 & 71,8 & 72,5 & 72,9 & 74,0 & 74,5 & 74,9 & 75,1 & 75,9 & 76,4 & 476,4 & 477,1 & 76,9 & 76,9 & 77,1 \\
\hline Rostov-on-Don & 74,2 & 73,5 & 73,3 & 73,5 & 72,5 & 72,3 & 72,1 & 73,0 & 73,3 & 73,7 & 73,9 & 73,4 & 73,6 & 73,9 & 74,3 & 74,5 & 574,2 & 275,1 & 75,9 & 76,6 & 76,6 & 77,4 & 477,6 & 577,6 & 58,1 & 78,2 & 78,0 \\
\hline Samara & 74,5 & 74,6 & 74,8 & 74,2 & 72,3 & 71,6 & 72,3 & 73,0 & 73,8 & 73,2 & 72,1 & 72,1 & 72,8 & 72,8 & 72,9 & 73,6 & 574,0 & 74,1 & 74,4 & 74,4 & 74,3 & 75,7 & 776,3 & 375,7 & 76,4 & 76,6 & 76,9 \\
\hline Saint Petersburg & 74,3 & 74,2 & 74,1 & 73,5 & 70,5 & 70,8 & 72,1 & 73,7 & 74,6 & 73,6 & 73,0 & 73,1 & 73,0 & 73,2 & 73,9 & 74,3 & 375,2 & 276,0 & 76,3 & 76,7 & 76,9 & 77,7 & 777,8 & 38,4 & 78,7 & 78,4 & 78,9 \\
\hline Ufa & 74,8 & 76,2 & 76,2 & 75,5 & 73,8 & 73,7 & 73,3 & 74,0 & 74,8 & 74,3 & 74,4 & 73,9 & 73,5 & 73,4 & 73,8 & 74,2 & 275,2 & 275,1 & 75,5 & 76,3 & 75,9 & 76,0 & 76,9 & 77,4 & 77,2 & 77,4 & 77,8 \\
\hline Chelyabinsk & 75,0 & 74,8 & 74,7 & 74,8 & 72,7 & 72,0 & 72,3 & 73,4 & 74,7 & 73,5 & 73,4 & 73,2 & 72,8 & 73,0 & 73,6 & 73,7 & 774,5 & 75,3 & 75,9 & 76,6 & 76,7 & 76,9 & 976,6 & 577,6 & 77,6 & 77,6 & 78,1 \\
\hline
\end{tabular}

\section{Both sexes}

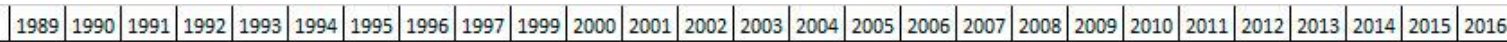

\begin{tabular}{|c|c|c|c|c|c|c|c|c|c|c|c|c|c|c|c|c|c|c|c|c|c|c|c|c|c|c|c|}
\hline Volgograd & 71,2 & 71,2 & 71,0 & 70,4 & 68,1 & 66,0 & 66,5 & 67,9 & 68,4 & 67,2 & 67,0 & 66,7 & 67,0 & 67,0 & 68,1 & 68,1 & 68,8 & 70,1 & 70,7 & 71,1 & 70,9 & 71,9 & 72,2 & 72,7 & 72,8 & 73,1 & 73,5 \\
\hline Joronezh & 72,4 & 72,5 & 71,8 & 71,3 & 69,0 & 68,3 & 68,2 & 69,3 & 70,2 & 68,1 & 67,5 & 67,2 & 67,1 & 66,7 & 67,1 & 67,2 & 67,9 & 68,2 & 69,2 & 70,2 & 70,7 & 71,8 & 72,3 & 72,4 & 72,0 & 72,8 & 73,1 \\
\hline katerinbu & 70,5 & 69,7 & 69,4 & 67,7 & 65,0 & 64,4 & 65,2 & 66,4 & 68,2 & 66,8 & 65,8 & 66,4 & 66,5 & 66,4 & 67,2 & 67,5 & 68,7 & 69,6 & 69,8 & 70,6 & 71,4 & 71,8 & 71,8 & 72,5 & 72,4 & 72,7 & 72,8 \\
\hline Kazan & 70,3 & 70,2 & 70,3 & 70,0 & 68,0 & 66,3 & 66,2 & 68,2 & 68,4 & 68,1 & 67,3 & 67,4 & 67,6 & 67,5 & 67,2 & 67,7 & 69,1 & 70,1 & 70,9 & 71,6 & 70,7 & 72,0 & 72,9 & 73,3 & 73,4 & 74,2 & 74,8 \\
\hline Krasnoya & 68,6 & 67,8 & 67,3 & 65,8 & 61,7 & 60,6 & 61,8 & 63,4 & 65,1 & 64,0 & 63,5 & 64,6 & 64,8 & 65,0 & 66,2 & 65,9 & 68,0 & 68,6 & 69,6 & 70,5 & 70,6 & 71,1 & 71,1 & 72,0 & 72,0 & 72,4 & 72,7 \\
\hline loscow & 69,9 & 69,8 & 69,9 & 68,9 & 65,7 & 64,3 & 65,3 & 68,1 & 69,5 & 69,7 & 69,7 & 69,5 & 69,8 & 70,0 & 70,8 & 71,5 & 72,1 & 73,0 & 73,3 & 74,1 & 74,2 & 75,8 & 75,7 & 76,4 & 76,7 & 76,8 & 77,1 \\
\hline Nijni Novgoro & 70,5 & 70,1 & 70,3 & 69,2 & 66,1 & 63,8 & 63,9 & 66,5 & 68,0 & 67,4 & 66,2 & 66,1 & 65,5 & 64,9 & 65,2 & 65,2 & 66,0 & 66,9 & 67,4 & 68,5 & 67,9 & 69,8 & 69,7 & 70,6 & 70,7 & 71,3 & 71,4 \\
\hline V & & & & 68,9 & 64,9 & 63,7 & 66,0 & 5,9 & 68,2 & 68,3 & 67,9 & 67,3 & 66,9 & 66,7 & 66,8 & 6,2 & 8,0 & 68,7 & 69,7 & 70,6 & 71,0 & 71,4 & 1,4 & 71,9 & 72,0 & 72,6 & 72,8 \\
\hline msk & & 1,6 & 0,9 & 70,3 & 67,6 & 66,2 & 67,0 & 67,9 & 68,2 & 67,8 & 66,9 & 67,4 & 66,8 & 66,4 & 66,7 & 66,0 & 67,1 & 67,8 & 69,0 & 70,1 & 70,3 & 71,3 & 71,1 & 71,4 & 71,7 & 72,0 & 72,4 \\
\hline Perm & & 9,9 & 69,6 & 68,4 & 65,4 & 64,0 & 3,9 & 65,5 & 67,4 & 66,3 & 65,8 & 65,8 & 65,8 & 65,1 & 65,4 & 6,0 & 67,5 & 68,6 & 68,8 & 69,3 & 69,8 & 70,7 & 70,9 & 71,6 & 1,6 & 71,5 & 72,0 \\
\hline Rostov-c & & & 69,0 & 68,7 & 66,7 & 65,7 & 65,7 & & & 68,9 & 68,1 & 67,7 & 67,6 & 67,9 & 68,6 & & 69,0 & 70,2 & 71,0 & 71,9 & 72,1 & 72,7 & 73,2 & 73,6 & 73,5 & 74,2 & 74,1 \\
\hline Samara & 69,9 & 69,6 & 69,8 & 68,6 & 66,1 & 64,6 & 65,2 & 65,7 & 67,5 & 65,7 & 64,0 & 64,3 & 65,7 & 65,7 & 65,6 & 66,5 & 67,1 & 67,3 & 67,8 & 68,2 & 68,1 & 69,5 & 70,2 & 69,7 & 69,9 & 70,7 & 71,6 \\
\hline Saint Petersburg & 70,3 & 69,8 & 69,6 & 68,2 & 63,8 & 63,9 & 65,8 & 68,3 & 69,8 & 67,9 & 66,7 & 66,9 & 67,1 & 67,1 & 67,5 & 68,0 & 69,3 & 70,4 & 71,0 & 71,8 & 72,1 & 73,1 & 73,4 & 74,2 & 74,6 & 74,4 & 74,9 \\
\hline Ufa & 70,6 & 71,7 & 71,0 & 70,4 & 67,7 & 66,7 & 66,9 & 68,3 & 69,2 & 68,3 & 67,9 & 67,7 & 67,3 & 67,0 & & 68,0 & 68,9 & 69,2 & 69,7 & 71,1 & 70,5 & 70,7 & 71,3 & 71,7 & 71,5 & 71,8 & 72,5 \\
\hline Chelyabinsk & 70,6 & 70,5 & 70,5 & 69,2 & 66,3 & 64,8 & 65,1 & 67,0 & 68,7 & 67,5 & 66,5 & 66,6 & 66,3 & 66,4 & 67,0 & 66,9 & 68,2 & 69,7 & 69,8 & 70,7 & 70,9 & 71,3 & 71,2 & 71,7 & 71,7 & 72,0 & 72,4 \\
\hline
\end{tabular}


Appendix 5. The average life expectancy at birth and the standard deviation for 11 Russian million-plus cities, 1989-2016

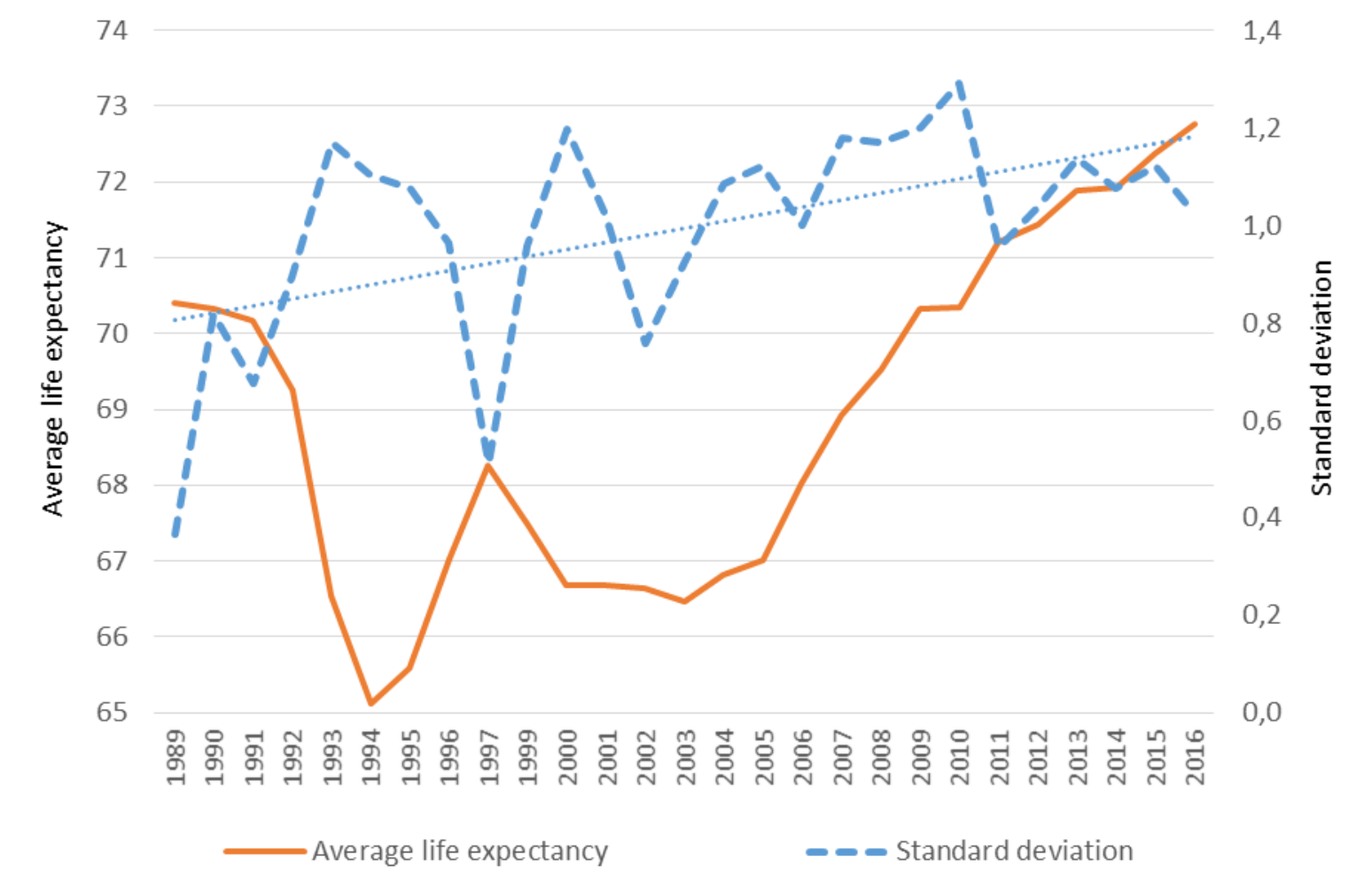

Appendix 6. Life expectancy at birth in Moscow, Saint Petersburg, Moscow, Leningrad oblasts, in 1989 and 2016, (in years)

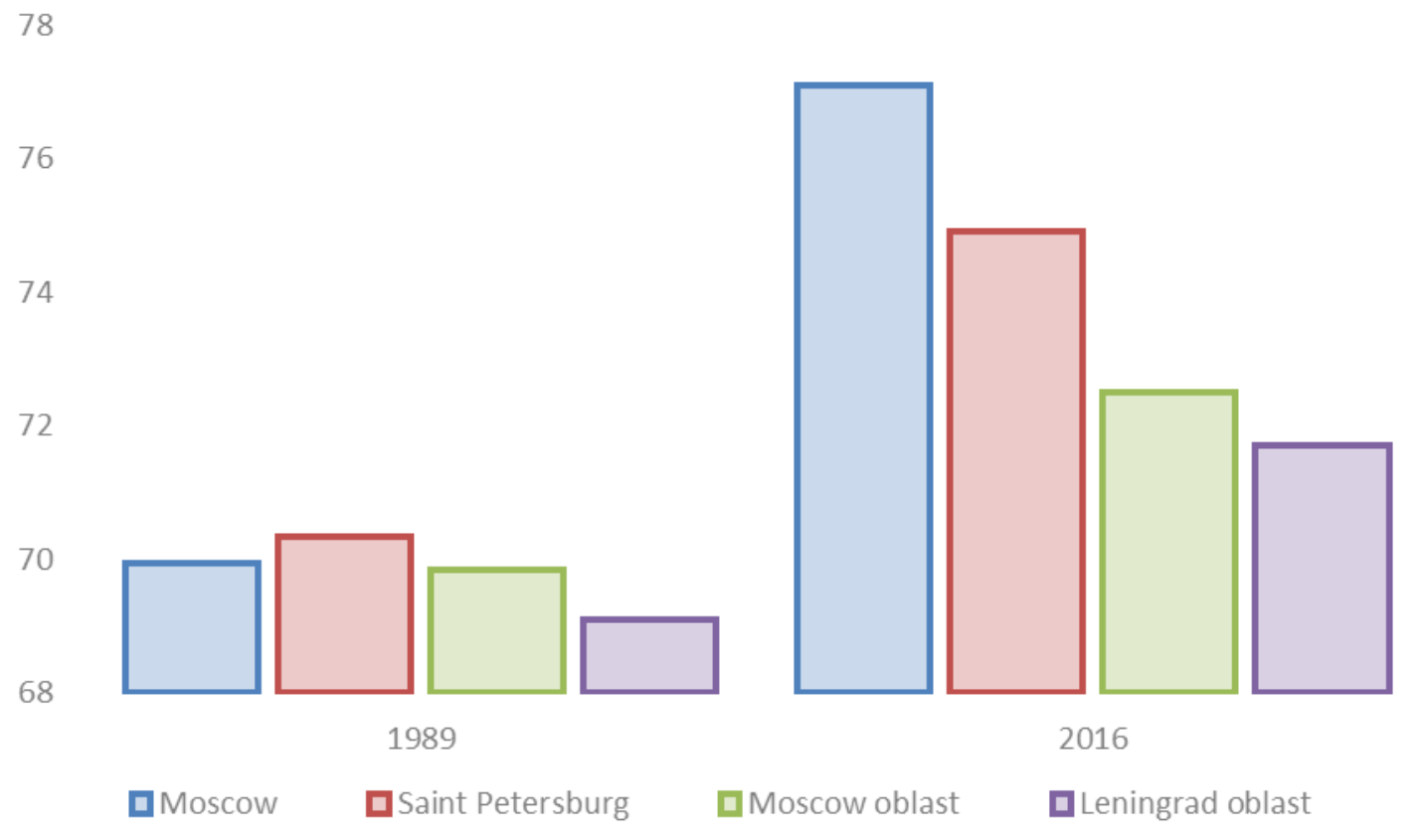




\section{Appendix 7. Gross urban / regional product (PPP) per capita, share of regional centers in the population and economy of the regions (\%), 2015}

\begin{tabular}{|c|c|c|c|c|c|c|}
\hline Regional center & $\begin{array}{c}\text { Share in } \\
\text { populatio } \\
n\end{array}$ & $\begin{array}{c}\text { Share in } \\
\text { econom } \\
y\end{array}$ & $\begin{array}{l}\text { Per capita } \\
\text { CUP } \\
\text { (PPP) }\end{array}$ & $\begin{array}{l}\text { Without regional } \\
\text { center }\end{array}$ & $\begin{array}{c}\text { Per capita CUP } \\
(\mathrm{PPP})\end{array}$ & $\begin{array}{l}\text { Ratio in per } \\
\text { capita } \\
\text { GUP/CRP }\end{array}$ \\
\hline Voronezh & 44 & 53 & 443415 & Voronezh oblast & 308789 & 1,4 \\
\hline Volgograd & 40 & 52 & 412512 & Volgograd oblast & 247458 & 1,7 \\
\hline Rostov-on-Don & 26 & 51 & 544149 & $\begin{array}{l}\text { Rostov-on-Don } \\
\text { oblast }\end{array}$ & 186162 & 2,9 \\
\hline Ufa & 27 & 42 & 529585 & Bashkiria & 278678 & 1,9 \\
\hline Kazan & 31 & 29 & 493054 & Tatarstan & 550379 & 0,9 \\
\hline Perm & 39 & 48 & 503968 & Perm krai & 348356 & 1,4 \\
\hline $\begin{array}{l}\text { Nizhny } \\
\text { Novgorod }\end{array}$ & 39 & 67 & 576344 & $\begin{array}{l}\text { Nizhny Novgorod } \\
\text { oblast }\end{array}$ & 181284 & 3,2 \\
\hline Samara & 36 & 47 & 510516 & Samara oblast & 333787 & 1,5 \\
\hline Ekaterinburg & 33 & 48 & 600234 & Sverdlovsk oblast & 326130 & 1,8 \\
\hline Krasnoyarsk & 37 & 35 & 546445 & Krasnoyarsk krai & 585336 & 0,9 \\
\hline Novosibirsk & 57 & 73 & 465241 & Novosibirsk oblast & 234433 & 2,0 \\
\hline Omsk & 59 & 77 & 467445 & Omsk oblast & 199093 & 2,3 \\
\hline Chelyabinsk & 34 & 45 & 501040 & $\begin{array}{l}\text { Chelyabinsk } \\
\text { oblast }\end{array}$ & 310423 & 1,6 \\
\hline Total city & 37 & 48 & 509167 & Total region & 320640 & 1,6 \\
\hline Moscow & 63 & 78 & 804822 & Moscow oblast & 389152 & 2,1 \\
\hline Saint Petersburg & 75 & 79 & 598312 & Leningrad oblast & 458943 & 1,3 \\
\hline $\begin{array}{l}\text { All millionare } \\
\text { cities }\end{array}$ & & & 633613 & $\begin{array}{l}\text { (excluding Crimea } \\
\text { and North } \\
\text { Caucasus) }\end{array}$ & 372607 & 1,7 \\
\hline
\end{tabular}

Note: For Moscow and St. Petersburg, the share of the total population of these cities and their surrounding areas (Moscow and Leningrad oblasts respectively)

Sources: Gross urban product - Rating of capital cities of Russia from the Institute for Urban Economics Foundation" 10 Gross regional product - Rosstat data. Purchasing power parity by city - "Cost of living index for selected cities of the Russian Federation" "1. The rest is the author's calculations.

${ }^{10}$ URL: http://www.urbaneconomics.ru/centr-obshchestvennyh-svyazey/news/reyting-stolichnyh-gorodov-rossii-otfonda-institut-ekonomiki\#_ftn1 (accessed: 27.10.2018).

${ }^{11}$ Rosstat. URL: http://www.gks.ru/free_doc/new_site/prices/isj/files/itogi_isj.pdf (accessed: 27.10.2018). 